\title{
Mesenchymal Stromal Cells in Transplantation Rejection and Tolerance
}

\author{
Karen English ${ }^{1}$ and Kathryn J. Wood ${ }^{2}$ \\ ${ }^{1}$ Cellular Immunology Group, Institute of Immunology, National University of Ireland Maynooth, \\ County Kildare, Ireland \\ ${ }^{2}$ Transplantation Research Immunology Group, Nuffield Department of Surgical Sciences, John \\ Radcliffe Hospital, University of Oxford, Oxford 0X3 9DU, United Kingdom \\ Correspondence: karen.english@nuim.ie
}

\begin{abstract}
Mesenchymal stromal cells (MSCs) have recently emerged as promising candidates for cellbased immunotherapy in solid organ transplantation (SOT). In addition to immune modulation, MSCs possess proreparative properties and preclinical studies indicate that MSCs have the capacity to prolong graft survival and in some cases induce tolerance. Currently, the application of MSCs in SOT is being evaluated in phase I/II clinical trials. Whereas the mechanisms of action used by MSC immunomodulation have been somewhat elucidated in vitro, the data from preclinical transplant models have been unclear. Furthermore, the optimal timing, dose, and route of administration remain to be elucidated. Importantly, MSCs have the ability to sense their environment, which may influence their function. In this article, we discuss the impact of the local microenvironment on MSCs and the mechanisms of MSC immunomodulation in the setting of SOT.
\end{abstract}

M esenchymal stromal cells (MSCs) are a subpopulation of multipotent cells originally identified in the bone marrow (Friedenstein et al. 1976). MSCs are characterized by their fibroblast-like appearance, colony forming unit capacity, and their rapid adherence to tissue culture plastic. Although MSCs are relatively easy to isolate, culture, and expand (from a number of tissues), the lack of a unique marker to identify MSCs has impacted the advancement of this research field as difficulties arise in comparing data using different MSC populations. In 2006, the International Society for Cellular Therapy proposed a set of phenotypic and functional criteria to define MSCs (Dominici et al. 2006), however, the discovery of new markers that specifically identify MSCs are eagerly awaited. MSCs have the capacity to differentiate into adipocytes, chondrocytes, and osteoblasts in vitro and in vivo (Pittenger et al. 1999). Based on the differentiation potential of MSCs, initially studies focused on the regenerative capacity of these cells (Mahmood et al. 2003; Murphy et al. 2003); however, over time, it became clear that MSCs mediated their effects predominantly through the production of trophic factors (Caplan and Dennis 2006; Prockop 2009). Indeed, some of these trophic

Editors: Laurence A. Turka and Kathryn J. Wood

Additional Perspectives on Transplantation available at www.perspectivesinmedicine.org

Copyright (C) 2013 Cold Spring Harbor Laboratory Press; all rights reserved; doi: 10.1101/cshperspect.a015560

Cite this article as Cold Spring Harb Perspect Med 2013;3:a015560 
factors facilitate MSC modulation of immune responses.

One of the first reports describing MSC immunosuppressive capacity was in fact a transplant model that showed that allogeneic (donor derived) MSCs prolonged allogeneic (donor and third-party-derived) skin graft survival (Bartholomew et al. 2002). Around the same time, Di Nicola et al. (2002) showed that MSCs mediated their suppressive effect through secretion of soluble factors. A significant body of data now supports an immunosuppressive capacity for MSCs both in vitro and in vivo. At the outset, studies focused primarily on MSC suppression of the adaptive immune response showing that MSCs can directly inhibit T-cell function, shift the T-helper lymphocyte balance, induce T-cell apoptosis, and induce functional regulatory $\mathrm{T}$ cells (Treg) (Kong et al. 2009; Ge et al. 2010; Akiyama et al. 2012). With respect to B cells, the available data are sparse and in some cases contradictory, but some studies suggest that MSCs can also suppress B-cell proliferation and function (Comoli et al. 2008). Recent findings convincingly show that MSCs modulate multiple components of the innate immune system including complement, toll-like receptor (TLR) signaling, macrophages, dendritic cells neutrophils, mast cells, and natural killer cells (Spaggiari et al. 2006; English et al. 2008; Kim and Hematti 2009; Nemeth et al. 2009; Cutler et al.2010; Choi et al.2011). Therapeutic efficacy of MSC anti-inflammatory effects has been established in a number of preclinical models including graft versus host disease, sepsis, inflammatory bowel disease, and allergic airway disease (Polchert et al. 2008; Ren et al. 2008; Nemeth et al. 2009; Kavanagh and Mahon 2011; Akiyama et al. 2012). In the case of solid organ transplantation (SOT), MSCs exert their effects on two fronts through attenuation of ischemia reperfusion injury (Liu et al. 2012a) and through the prevention of allograft rejection (Casiraghi et al. 2008; Ding et al. 2009; Ge et al. 2010). Moreover, in some cases, MSC induce a state of tolerance (Ge et al.2010; Casiraghi et al. 2012). The in vitro immunosuppressive capacity, combined with the proven therapeutic efficacy of MSCs in preclinical models, has paved the way for MSCs in clinical application. Further evidence of a protective role for MSCs in preclinical models of organ transplantation in combination with the reported safety of MSCs in clinical trials has prompted the evaluation of safety and efficacy of MSCs in SOT (Tan et al. 2012). Herein, we will discuss the underlying mechanisms of MSC immunomodulation in the context of ischemia reperfusion injury, prevention of allogeneic graft rejection, and induction of tolerance.

\section{REJECTION}

\section{Mechanisms of Transplantation Rejection}

Despite the significant achievements accomplished during the past 60 years in SOT, rejection remains the greatest barrier (Wood and Goto 2012; Wood et al. 2012). Whereas, the advent of immunosuppressive drugs has facilitated improved outcomes in graft survival and long term function, the toxicity and associated complications of nonspecific immunosuppression are substantial limiting factors (Halloran 2004). Thus, there is a significant unmet need for nontoxic immunosuppressive therapies.

The immune response to an allograft is an ongoing process involving both innate and adaptive components starting from the moment of reperfusion. In fact, the tissue injury associated with organ retrieval (ischemic injury) initiates the production of damage-associated molecular patterns (DAMPs) and subsequent activation of the complement system and innate immune cells (macrophages and neutrophils) through pathogen recognition receptors (PRRs) (Eltzschig and Eckle 2011) after reperfusion and initiates a local inflammatory environment. Activation of the innate immune response orchestrates the adaptive immune response. Although, graft rejection is multifactorial, alloantigen specific induction of T-cell proliferation and activation of T-cell effector functions is the major player in graft destruction. Antibody mediated rejection is triggered by alloantibody binding and complement activation and also significantly contributes to graft loss. Here, we discuss the effect of MSC on ischemia reperfusion injury and innate and 
adaptive components in the context of solid organ transplantation.

\section{ISCHEMIA REPERFUSION INJURY}

Effect of Mesenchymal Stromal Cells on Ischemia Reperfusion Injury

Ischemia reperfusion injury causes sterile inflammation and results in the production of a number of DAMPs including necrotic cells, cellular debris, heat shock proteins (HSPs), and high mobility group protein box-1 (HMGB1) (Eltzschig and Eckle 2011). DAMPs activate PPRs such as TLRs, C-type lectin receptors, nucleotide-binding oligomerization domain (NOD) and NOD-like receptors, receptor for advanced glycation endproducts (RAGE), and retinoic acid inducible gene-I receptors. Signaling through these receptors results in activation of the inflammasome (Ogura et al. 2006) and the complement system, upregulating gene transcription and production of micro-RNAs (Eltzschig and Eckle 2011) involved in the inflammatory response. Together, these factors lead to the production of proinflammatory cytokines, the activation of platelets and endothelial cells, tissue hypoxia, and the recruitment of innate and eventually adaptive immune cells (Eltzschig and Eckle 2011).

MSCs are known to express a number of PRRs, including TLR1-9 (Pevsner-Fischer et al. 2007; Tomchuck et al. 2008; Opitz et al. 2009; Romieu-Mourez et al. 2009), NOD receptors (Kim et al. 2010; Sioud et al. 2010), and RAGE (Kume et al. 2005). These receptors are functionally active on MSCs, and binding to their respective ligands leads to alterations in MSC functions. For example, stimulation of NODlike receptors on MSC leads to the production of interleukin (IL)-8 and vascular endothelial growth factor (Kim et al. 2010; Sioud et al. 2010). HMGB-1 signaling through RAGE induced MSC migration and inhibited MSC production of indoleamine 2,3-dioxygenase (IDO) (Lotfi et al. 2011). TLR3 and TLR4 activation of MSCs resulted in differential effects with TLR4 priming inducing a proinflammatory phenotype and secretion of IL-6, IL-8, and transforming growth factor $\beta$ (TGF- $\beta$ ), whereas TLR3 priming induced anti-inflammatory MSCs producing IDO, prostaglandin E-2 (PGE-2), IL-4, and IL-1RA (Waterman et al. 2010). In regard to MSC immunosuppressive function, TLR3 and TLR4 enhanced MSC immunosuppression in vitro through IDO induction via IFN- $\beta$ and protein kinase R signaling (Opitz et al. 2009). In addition, TLR2 but not NOD-1 activation of human MSCs resulted in the upregulation of the immune suppressive protein galectin-3 (Sioud et al. 2010). In contrast, Liotta et al. (2008) showed that TLR3 and TLR4 ligand binding attenuated MSC immunosuppressive effects. It is clear that MSCs are receptive to environmental cues that may be present during ischemia reperfusion injury, however, further research is required to understand how these DAMPs effect MSCs and whether or not they play a role in determining the function of MSCs.

MSCs are also responsive to complement and migrate in response to $\mathrm{Clq}, \mathrm{C} 3 \mathrm{a}$, and C5a (Schraufstatter et al. 2009; Qiu et al. 2012), and high levels of C3 activation correlate with enhanced immunosuppressive capacity of MSCs (Moll et al. 2011). Importantly, MSCs express CD59, a complement regulatory protein, and also release complement factor $\mathrm{H}$ that protects them from complement lysis ( $\mathrm{Tu}$ et al. 2010; Moll et al. 2011). In addition, stimulation through $\mathrm{C} 3 \mathrm{aR}$ and $\mathrm{C} 5 \mathrm{aR}$ protect MSCs from oxidative damage (Schraufstatter et al. 2009) and MSCs produce a number of antioxidants including hemeoxygenase- 1 and superoxide dismutase (Kemp et al. 2010; Mougiakakos et al. 2011), and have been shown to suppress oxidative stress and inflammation in ischemia reperfusion injury models in vivo (Chen et al. 2011, 2012; Sun et al. 2011; Du et al. 2012). The exact mechanisms of action are unclear; however, MSC protection in these models was associated with increased expression of IL-10, heme oxygenase-1 (HO-1), and hepatocyte growth factor, decreased expression of the proinflammatory cytokines IL-1 $\beta$, TNF- $\alpha$, and interferon $\gamma$ $($ IFN- $\gamma)$, reduced reactive oxygen species, reduced apoptosis and decreased numbers of activated T cells, and infiltrating immune cells (Hara et al. 2011; Sun et al. 2011; Chen et al. 2012; Du et al. 2012). 
MSC derived microvesicles combined with soluble factors have been shown to protect against ischemia reperfusion induced acute and chronic kidney injury through inhibition of apoptosis and stimulation of tubular epithelial-cell proliferation (Gatti et al. 2011). Importantly, a protective effect of MSCs in ischemia reperfusion transplant models has been reported. Administration of MSCs reduced intragraft inflammatory gene expression and recruitment of antigen presenting cells into the allograft in a prolonged cold ischemic kidney transplant model (Hara et al. 2011) and provided long-term protection from chronic allograft nephropathy (Franquesa et al. 2012a). Ischemia reperfusion also plays a key role in the recruitment of MSCs to transplanted organs (Casiraghi et al. 2012). MSC recruitment mediated by ischemia reperfusion injury in combination with an ongoing alloreactive response leads to premature graft dysfunction and fails to prolong graft survival (Casiraghi et al. 2012). This study showed that although MSCs administered posttransplant promoted neutrophil infiltration and complement deposition, infusion of MSCs pretransplant induced significant allograft survival through a Treg dependent mechanism (Fig. 1) (Casiraghi et al. 2012). The key observation of this study is that MSCs infused pretransplant localize in the lymphoid organs whereas MSC administered posttransplant are recruited to the graft (syngeneic or allogeneic). Overall, it seems that MSCs can exert protective effects in ischemic reperfusion injuries through anti-inflammatory and paracrine factors and this likely plays an important part in MSC enhancement of allograft survival. However, there is still a lot to learn with regard to the effect of the ischemic environment on MSC functions and how this might impact MSC therapy in solid organ transplantation.

\section{TOLERANCE}

\section{Mesenchymal Stromal Cell Modulation of Macrophages}

Macrophages and neutrophils are generally the first innate immune cells to infiltrate the graft postischemia reperfusion injury. Whereas neutrophils are present only in the graft during inflammatory episodes, macrophages are present throughout the life of the graft, infiltrating in response to ischemia reperfusion injury, and maintained in reduced numbers after resolution of tissue injury in the absence of rejection. Neutrophils and macrophages have been shown to play a role in graft rejection through tissue damage induced by effector function, production of proinflammatory cytokines, and activation of antigen specific T cells (Wyburn et al. 2005). On the other hand, macrophages are also known to play a role in tissue repair and can be repolarized from pro to anti-inflammatory (Sica and Mantovani 2012). Although it has not been shown in a SOT setting, MSCs have the capacity to re-educate monocytes/ macrophages. MSCs induce alternatively activated macrophages down-regulating the production of TNF- $\alpha$, IL- $1 \alpha$, IL- 6 , and IL-12p70, and increasing the production of IL-10 and enhancing phagocytic activity (Kim and Hematti 2009; Nemeth et al. 2009; Cutler et al. 2010; Choi et al. 2011) through production of IDO and PGE-2 (Maggini et al. 2010; Francois et al. 2012).

Two important studies build a picture of how MSCs orchestrate macrophage polarisation and the influence the local microenvironment has on that process. Nemeth and colleagues show that MSCs ameliorate sepsis through alternative activation of macrophages, showing that lipopolysaccharide (LPS) and TNF- $\alpha$ activate TLR4 and tumor necrosis factor receptor 1 on MSCs to activate NF- $\kappa \mathrm{B}$ signaling. This, in turn, leads to the expression of cyclooxygenase (COX)-2 and synthesis of PGE-2 by MSCs that bind E-prostanoid 2/4 (EP2/EP4) receptors on macrophages resulting in increased production of IL-10 and facilitating the resolution of inflammation (Nemeth et al. 2009). In the second study, Prockop's group used a zymosan induced peritonitis model to show that MSCs exerted anti-inflammatory effects through the production of tumor necrosis factor $\alpha$ (TNF- $\alpha)$-induced protein 6 (TSG-6), which subsequently limits TLR2/NF- $\mathrm{B}$ signaling through direct interaction with CD44 expressed on the macrophage to initiate a negative feedback loop 
MSCs in Transplantation

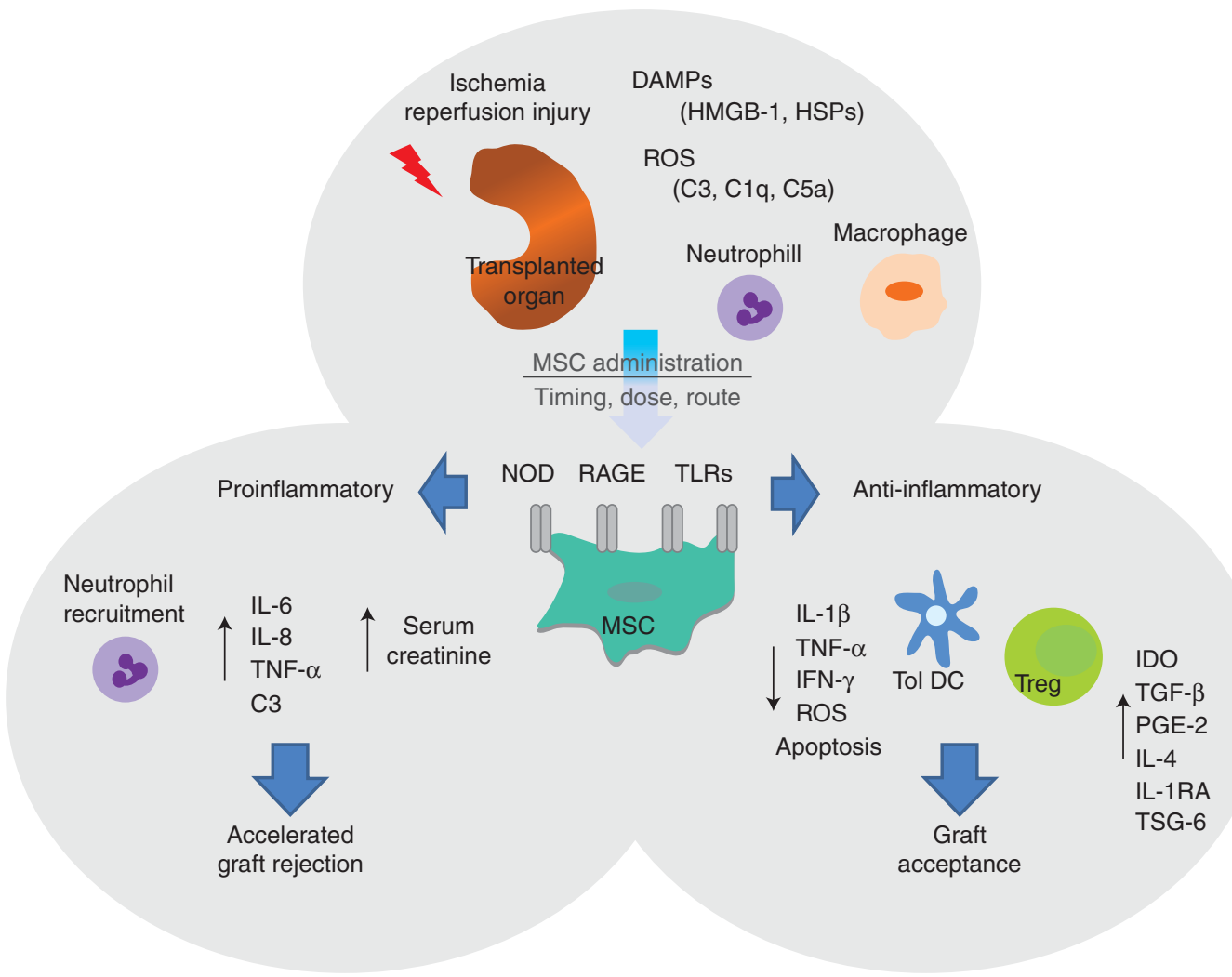

Figure 1. Influence of ischemia reperfusion injury on MSC function. Ischemia reperfusion injury (associated with organ retrieval) leads to the production of DAMPs including HMGB-1 and HSPs among others. Signaling through PRRs including TLRs, NOD receptors, and RAGE results in the activation of the complement system, recruitment of innate immune cells (neutrophils and macrophages), and the production of reactive oxygen species (ROS). Depending on the timing, dose, and route of administration, MSC given to patients in the context of SOT may encounter an ischemia reperfusion microenvironment. MSCs express a number of PRRs including NOD, RAGE, and TLRs, and activation of these receptors through DAMPs like HMGB-1 and HSPs may determine MSC function. Signaling through RAGE, NOD-like receptors, or TLR4 on MSC may lead to the promotion of a proinflammatory environment leading to the production of the proinflammatory cytokines IL-6, IL-8, and TNF- $\alpha$, neutrophil recruitment, and complement deposition resulting in elevated serum creatinine and accelerated graft rejection. Alternatively, activation of TLR3 on MSC may induce an anti-inflammatory milieu, reducing the production of proinflammatory cytokines (IL-1 $\beta$, TNF- $\alpha$, and IFN- $\gamma$ ), decreasing ROS and apoptosis, and generating tolerogenic dendritic cells and Treg facilitating graft acceptance.

inhibiting the inflammatory response (Choi et al. 2011). Although MSC secretion of TSG6 has been implicated in corneal allograft survival (Oh et al. 2012), it remains to be determined whether or not MSC derived TSG-6 can modulate macrophages in this setting. On the whole, microenvironmental cues present at the site of MSC activation seem to determine the particular mechanism of actions deployed by MSCs in modulating the immune response and resolving inflammation.

\section{Mesenchymal Stromal Cell Modulation of Dendritic Cells}

Dendritic cells (DCs) are sentinel cells and as such, present alloantigens activating antigen specific $\mathrm{T}$ cells. Both donor and recipient 
DCs play a critical role triggering graft rejection through the direct, indirect, or semi-direct pathways of allorecognition (Wood and Goto 2012). MSCs can interfere with the key features of DC function: migration, maturation, and antigen presentation (English et al. 2008), and mediate these effects through down-regulation of DC maturation markers including major histocompatibility complex (MHC) class II, CD40, CD80, and CD86 (Nauta et al. 2006a; Djouad et al. 2007; Li et al. 2008b; Zhang et al. 2009), and modulation of the lymph node homing chemokine receptor CCR7 in vitro (English et al. 2008) and in vivo (Chiesa et al. 2011). The soluble factor IL- 6 produced by MSCs has been shown to be involved in down-regulation of maturation markers (Nauta et al. 2006a; Djouad et al. 2007; English et al. 2008), whereas contact-dependent Notch signaling but not IL6 was shown to be required for DC modulation in another study (Li et al. 2008b). Further support of a role for Notch signaling in this scenario has been put forward by Zhang and colleagues (2009) showing contact-dependent Jagged-2 (a Notch ligand) signaling in the generation of regulatory DC. In the context of SOT, MSCs have been shown to block DC maturation and function in a kidney allograft model (Ge et al. 2010); however, the exact mechanisms used by MSCs to achieve this effect remains to be elucidated.

Analogous to the effects of MSCs on macrophage polarization, MSCs can also promote the generation of tolerogenic DCs ( $\mathrm{Li}$ et al. 2008a; Ge et al. 2009; Spaggiari et al. 2009; Zhang et al. 2009; Liu et al. 2012b) producing anti-inflammatory cytokines and displaying enhanced phagocytic activity (Zhang et al. 2009; Liu et al. 2012b) typical of tolerogenic DCs. MSC educated DCs have the capacity to suppress alloreactive responses and prolong islet allograft survival (Huang et al. 2010) and to induce a state of tolerance in the context of SOT (cardiac allograft) in the presence of low dose immunosuppression (Ge et al. 2009).

The mechanisms of action mediated by MSCs in the generation of tolerogenic DCs are likely influenced by the context in which MSCs see DCs. The key mediator in MSC modulation of DC maturation is IL-6 (Nauta et al. 2006a;
Djouad et al. 2007; English et al. 2008), however, the mechanism involved in MSC promotion of tolerogenic DCs has been less clear. Other studies have shown a central role for PGE-2 (Spaggiari et al. 2009) and cell contact-dependent activation of the Notch signaling pathway ( Li et al. 2008b; Zhang et al. 2009), but not IL-6 (Li et al. 2008b; Spaggiari et al. 2009) in MSC generation of tolerogenic DCs. Further evidence of a contact-dependent mechanism involving activation of AKT and impaired NF- $\kappa \mathrm{B}$ signaling has been proposed (Chiesa et al. 2011). Finally, it has been shown that mouse embryonic fibroblast derived MSCs generate a novel population of IL-10 dependent tolerogenic DCs through an IL-10 activated SOCS3 dependent mechanism (Liu et al. 2012b). MSC induction of tolerogenic DCs is a key mechanism involved in MSC modulation of immune responses; however, significant gaps in our understanding of exactly how MSCs promote the generation of tolerogenic DCs remain.

\section{Mesenchymal Stromal Cell Suppression of Allogeneic T-Cell Responses in Transplantation Rejection}

Allogeneic T-cell proliferation and activation are prerequisites for allograft rejection and induction of tolerance in allogeneic organ transplantation is usually associated with Treg (Issa et al. 2011; Wood et al. 2012). A large body of data convincingly show that autologous and allogeneic MSCs modulate T-cell proliferation, activation, and function both in vitro and in vivo (Di Nicola et al. 2002; Glennie et al. 2005; English et al. 2007; Asari et al. 2009; Ding et al. 2009; English and Mahon 2011). Moreover, in vitro assays have also confirmed the capacity for MSCs to inhibit Th17 cell differentiation (Duffy et al. 2011; Tatara et al. 2011) or to shift the T helper cell balance in favor of a more anti-inflammatory phenotype (Batten et al. 2006; Bai et al. 2009; English et al. 2009; Fiorina et al. 2009; Ghannam et al. 2010). The mechanisms used by MSCs in mediating these effects vary between in vitro and in vivo models. However, many of these effects are mediated through soluble factors secreted by MSCs (English 2013). 
IDO and PGE-2 have been implicated in MSC inhibition of Th17 differentiation (Duffy et al. 2011; Tatara et al. 2011). In the case of PGE-2, the steps involved in the process require contactdependent COX-2 induction of PGE-2 and direct inhibition through EP4 (Duffy et al. 2011). MSCs can also mediate this effect through suppressing the Th17 transcription factor ROR $\gamma t$ and upregulating Foxp3 to induce a Treg phenotype producing IL-10 (Ghannam et al. 2010). MSC derived TGF- $\beta$ has been shown to play a partial role in shifting the balance of Th1/Th2/ Th17 and Treg in an autoimmune disease model (Kong et al. 2009).

With regard to SOT, MSCs impaired alloreactive T-cell responses (Casiraghi et al. 2008, 2012; Ge et al. 2010) and inhibited the migration of activated $\mathrm{T}$ cells into the allograft (Eggenhofer et al. 2011b; Hara et al. 2011; Franquesa et al. 2012a). In particular, matrix metalloproteinase (MMP) 2 and MMP9 secreted by MSCs facilitated cleavage of CD25 expressed on CD $4{ }^{+} \mathrm{T}$ cells inhibiting alloantigen driven proliferation and preventing islet allograft rejection (Ding et al. 2009). Other evidence suggests that MSC derived MMPs also cleave CC chemokine ligand (CCL2), which subsequently inhibits Th17 activation via a STAT3 dependent pathway (Rafei et al. 2009). In addition, MSCs mediated their effects in part through shifting the balance of $\mathrm{T}$ helper 1 cell phenotype to a more anti-inflammatory Th2 phenotpye producing IL-4 and IL10 (Ge et al. 2010; Jia et al. 2012). Importantly, MSCs also have the capacity to expand or induce Treg in the setting of SOT (Casiraghi et al. 2008, 2012; Wang et al. 2009; Jia et al. 2012) and in some cases to generate a state of Treg-dependent tolerance (Ge et al. 2010; Casiraghi et al. 2012). Both of these studies elegantly show the importance of Treg in MSC induced tolerance using Treg depletion studies. Apart from the study by Ge et al. (2010), which identifies an important role for MSC derived IDO in the generation of Treg, the mechanisms of action mediated by MSCs remain to be elucidated. In vitro, the factors required for MSC induction of Treg are thought to involve cell contact, PGE-2, and TGF- $\beta$ (English et al. 2009). Further evidence for a contact-dependent role was provided by
Selmani and colleagues, showing that cell contact-dependent production of HLA-G5 was required for the expansion of Treg (Selmani et al. $2008)$. In vivo, MSC derived TGF- $\beta$ was required for the generation of antigen specific Treg and overall, TGF- $\beta$ seems to be the major soluble factor involved in MSC promotion of Treg in vivo (Zhao et al. 2008; Kong et al. 2009; Nemeth et al. 2010; Akiyama et al. 2012). MSC generation of Treg involves a number of different steps that are dependent on the specific environment or disease model. For example, Nemeth and colleagues (2010) showed that MSCs exposed to IL4 and IL-13 (typically produced in allergic environment) produced TGF- $\beta$ through an IL-4R/ STAT6 dependent pathway. Alternatively, MSCs may induce Treg indirectly through modulation of innate immune cells. A study performed by Akiyama et al. examining the effect of MSCs in a mouse model of dextran sodium sulfateinduced colitis, unravelled a complex course of events that ultimately led to the expansion of Treg. Specifically, MSCs induced T effector cell apoptosis through FAS/FASL facilitated by MSC MCP-1 chemoattraction of T cells. Subsequently, macrophages produce TGF- $\beta$ following phagocytosis of the apoptotic cell debris resulting in the expansion of Treg (Akiyama et al. 2012).

\section{INTERACTION OF MESENCHYMAL STROMAL CELLS WITH ALLOREACTIVE B CELL RESPONSES}

The triggering of antibody mediated rejection by alloantibody binding and complement activation is increasingly associated with graft loss (Wood and Goto 2012). The reported effects of MSCs on B-cell activation, proliferation, and function have been variable and in some cases contradictory. MSCs have been shown to inhibit B-cell proliferation (Augello et al. 2005; Corcione et al. 2006; Asari et al. 2009; Schena et al. 2010) and immunoglobulin (Ig) production (Corcione et al. 2006; Comoli et al. 2008; Rafei et al. 2008) in vitro. The mechanisms of action involve contact-dependent factors (Schena et al. 2010) including programmed death-1 [PD-1]/programmed death-ligand [PD- 
L1]/PD-L2 (Augello et al. 2005) as well as soluble factors like MMP cleaved CCL2 (Rafei et al. 2008). MSC inhibition of plasma cells induced by LPS or plasmacytoid DCs was shown to be mediated through extracellular signal-related kinases (ERK) $1 / 2$ and phosphorylation of p38 (Tabera et al. 2008; Asari et al. 2009). Moreover, MSCs induced cell cycle arrest in B cells (Corcione et al. 2006), and particularly under highly proliferative conditions (Traggiai et al. 2008). In contrast, MSCs also have the capacity to promote B-cell proliferation and survival (Tabera et al. 2008; Traggiai et al. 2008; Youd et al. 2010) and enhance Ig production (Rasmusson et al. 2007; Youd et al. 2010). Considerable variations are reported in these findings with MSCs increasing IgM but not IgA or IgG in another study (Traggiai et al. 2008) with differences in the mechanisms involved (contact-dependent versus soluble factors) depending on the source of B cells (purified versus peripheral blood mononuclear cells or mononuclear cells) (Rasmusson et al. 2007) and the ratio of MSCs to B cells in co-cultures (Franquesa et al. 2012b). These differences may well be resolved by ensuring purity of B cells (excluding T-cell help) and by further understanding the effect that TLR ligands (LPS, cytosine phosphodiester guanine, polyinosinic:polycytidylic acid) have on MSC activation and function. The effect of MSCs has also been examined in the B cell driven pathology systemic lupus erythematosus (SLE) both in mouse models and in patient samples. MSC enhanced survival and reduced serum creatinine, blood urea nitrogen, proteinuria, C3 deposition, and decreased circulating double-stranded deoxyribonucleic acid (dsDNA) antibodies as well as antigen specific IgM and IgG secretion (Zhou et al. 2008; Asari et al. 2009; Choi et al. 2011). In contrast, Schena et al. (2010) reported no effect of MSCs on survival, proteinuria, or dsDNA antibodies. Furthermore, MSCs were shown to negatively impact SLE through enhancing pathology, autoantibody production, and proteinuria (Youd et al. 2010). In the setting of SOT, much of the focus has been on the effect of MSCs on T cells (discussed above), and to our knowledge, no study has rigorously examined the impact of MSC on al- loreactive B cells. Nonetheless, there are reports that suggest that MSCs reduce intragraft IgG deposits as well as circulating donor specific antibodies (Ge et al. 2009; Franquesa et al. 2012a) providing protection from injury (Franquesa et al. 2012a) and inducing allograft tolerance in the presence of immunosuppression (Ge et al. 2009). Notably, failure of MSCs to prolong allograft survival has been associated with MSC promotion of intragraft B cell infiltration (Seifert et al. 2012), and although administration of donor MSCs posttransplant lead to sensitization and premature graft dysfunction, this was not thought to be associated with antibody mediated humoral rejection $(\mathrm{Ca}$ siraghi et al. 2012). Rather, syngeneic MSCs administered posttransplant (but not pretransplant) localized in the transplanted kidney in response to ischemia reperfusion injury and subsequently produced IL- 6 and TNF- $\alpha$ promoting a proinflammatory environment facilitating neutrophil infiltration and C3 deposition (Casiraghi et al. 2012). These studies highlight the significant gap in our understanding of the effect of the microenvironment on MSC activation and function and particularly the effect this has on how MSCs see B cells and vice versa.

\section{Immunogenicity of Allogeneic Mesenchymal Stromal Cells}

Although, allogeneic MSCs were thought to be immune privileged, evidence now suggests that allogeneic MSCs are recognized by the innate and adaptive immune system (Griffin et al. 2013). A clear understanding of how recognition of allogeneic MSCs impacts their capacity for modulating immune responses in vivo is hampered by the lack of appropriate experimental data measuring antidonor T-cell and antibody responses to allogeneic MSC. Nevertheless, a small number of studies show that allogeneic MSC evoke antidonor T-cell and antibody responses in vivo in healthy animals as well as models of myocardial infarction and bone marrow transplantation (Eliopoulos et al. 2005; Beggs et al. 2006; Nauta et al. 2006b; Badillo et al. 2007; Poncelet et al. 2008; Zangi et al. 2009; Isakova et al. 2010; Schu et al. 2012). 
In the SOT setting, allogeneic MSC have been shown to accelerate graft rejection (Inoue et al. 2006; Popp et al. 2008; Renner et al. 2009; Eggenhofer et al. 2011a,b; Seifert et al. 2012). In some cases, accelerated graft rejection was attributed to administration of allogeneic MSC pretransplant (Eggenhofer et al. 2011b; Seifert et al. 2012) or syngeneic MSC posttransplant (Casiraghi et al. 2012). In other cases, allogeneic or syngeneic MSC were shown to attenuate immunosuppressive drugs like cyclosporine A (Inoue et al. 2006). Importantly, allogeneic MSCs have the capacity to work in synergy with immunosuppressive drugs including mycophenolate mofetil (Eggenhofer et al. 2011a,b) and rapamycin (Ge et al. 2009), and in these studies promote graft survival. Perhaps these studies emphasize the impact that different microenvironments may have on allogeneic MSC immunogenicity as well as the immunosuppressive function of both syngeneic and allogeneic MSCs in vivo. These conflicting reports highlight the significant need for further research in this area.

\section{CLINICAL APPLICATION OF MESENCHYMAL STROMAL CELLS IN SOLID ORGAN TRANSPLANTATION}

The application of MSC therapy in conjunction with a reduced immunosuppressive regimen is theoretically very appealing as MSCs not only promote the resolution of inflammation and enhance graft repair, but also may facilitate the induction of tolerance. Based on the safety and efficacy data generated in preclinical models and clinical trials utilizing MSC therapy for acute graft versus host disease (Casiraghi et al. 2008; LeBlanc et al. 2008; Ge et al. 2010), MSC therapy is currently being evaluated in SOT (Hoogduijn et al. 2010). Perico and colleagues (2011) provided the first report on MSCs in kidney transplant patients in a pilot study examining safety and feasibility. Culture expanded autologous bone marrow derived MSCs $(1.7 \times$ $10^{6}-2.0 \times 10^{6} / \mathrm{kg}$ body weight) were administered intravenously on day 7 postkidney (living donor) transplant in addition to T-cell depletion induction therapy in two patients. This study reported an increase in serum creatinine in both patients 7-14 days after MSC infusion. In addition, a focal inflammatory (granulocyte) infiltrate was observed in a graft biopsy taken from one of the patients, but acute graft rejection was ruled out. Importantly, both patients maintained stable graft function, which was associated with decreased memory $\mathrm{CD}^{+}{ }^{+} \mathrm{T}$ cells and increased Treg (Perico et al. 2011). Notably, similar effects were observed in a mouse model of kidney allograft transplantation, and this study elegantly showed the correlation of premature graft injury with posttransplant (but not pretransplant) syngeneic MSC infusion and localization of the MSCs primarily in the injured graft (Casiraghi et al. 2012). Indeed these studies may help to resolve the disparate findings with regard to MSC efficacy in prolonging graft survival (Inoue et al. 2006; Popp et al. 2008; Renner et al. 2009; Eggenhofer et al. 2011a,b; Seifert et al. 2012). This highlights the importance of timing of MSC administration and the requirement for a better understanding of the influence of the transplanted graft microenvironment (ischemia reperfusion, for example) on MSC function (Fig. 1). A large randomized controlled trial (106 patients over three arms) investigating the safety and efficacy of autologous bone marrow derived MSCs (in kidney transplantation) in combination with standard dose calcineurin inhibitors (CNI), or low dose CNI were compared with control groups receiving anti-IL-2 receptor antibody therapy in combination with standard dose CNI (Tan et al. 2012). This trial showed safety and efficacy with decreased incidence of acute rejection and glucocorticoid-resistant rejection, and increased estimated glomerular filtration rate levels and faster recovery of renal function in the first month post transplant as well as better estimated renal function at year 1. In addition, MSC treated groups revealed significantly reduced risk of opportunistic infections than the control group (Tan et al. 2012). Importantly, this large randomized controlled trial did not observe increased creatinine levels in MSC treated patients and this may be associated with the dose and/or timing $\left(1-2 \times 10^{6}\right.$ on day 0 and day 14 versus $1.7-2 \times 10^{6}$ on day 7 posttransplant) of 
MSC administration or with differences in immunosuppressive regimen (Perico et al. 2011; Tan et al. 2012). These are important factors that may significantly impact MSC efficacy in SOT and require careful consideration.

\section{CONCLUDING REMARKS}

Although the capacity for MSCs to modulate immune responses in vitro has been undeniable, the in vivo immunosuppressive function of MSCs has, at times, been ambiguous. Over time it has become clear that MSCs are receptive to microenvironmental cues, and indeed evidence has emerged to suggest that the interactions between MSCs and the local environment are fundamental in determining MSC activation and function. In vivo models have shown that MSCs are responsive to ischemia reperfusion injury and can provide protection in this setting. Moreover, MSCs have the capacity to prolong graft survival and, indeed, may induce tolerance. Together, these characteristics make MSCs an ideal candidate for application in SOT, and early data from clinical trials suggest that MSCs are safe and efficacious, but highlight the gap in our understanding of how exactly MSCs mediate their protective effects in vivo. To this end, we must endeavor to fill these gaps and enhance MSC therapeutic efficacy.

\section{ACKNOWLEDGMENTS}

Karen English is supported by an HRB Translational Medicine Postdoctoral Fellowship and a Marie Curie Career Integration Grant. Work from the authors' own laboratories is supported by grants from The Wellcome Trust, European Union FP7 Programme (OPTISTEM), and the Medical Research Council, United Kingdom.

\section{REFERENCES}

Akiyama K, Chen C, Wang D, Xu X, Qu C, Yamaza T, Cai T, Chen W, Sun L, Shi S. 2012. Mesenchymal-stem-cell-induced immunoregulation involves FAS-ligand-/FASmediated T cell apoptosis. Cell Stem Cell 10: $544-555$.

Asari S, Itakura S, Ferreri K, Liu CP, Kuroda Y, Kandeel F, Mullen Y. 2009. Mesenchymal stem cells suppress B-cell terminal differentiation. Exp Hematol 37: 604-615.
Augello A, Tasso R, Negrini SM, Amateis A, Indiveri F, Cancedda R, Pennesi G. 2005. Bone marrow mesenchymal progenitor cells inhibit lymphocyte proliferation by activation of the programmed death 1 pathway. Eur $J$ Immunol 35: 1482-1490.

Badillo AT, Beggs KJ, Javazon EH, Tebbets JC, Flake AW. 2007. Murine bone marrow stromal progenitor cells elicit an in vivo cellular and humoral alloimmune response. Biol Blood Marrow Transplant 13: 412-422.

Bai L, Lennon DP, Eaton V, Maier K, Caplan AI, Miller SD, Miller RH. 2009. Human bone marrow-derived mesenchymal stem cells induce Th2-polarized immune response and promote endogenous repair in animal models of multiple sclerosis. Glia 57: 1192-1203.

Bartholomew A, Sturgeon C, Siatskas M, Ferrer K, McIntosh K, Patil S, Hardy W, Devine S, Ucker D, Deans R, et al. 2002. Mesenchymal stem cells suppress lymphocyte proliferation in vitro and prolong skin graft survival in vivo. Exp Hematol 30: 42-48.

Batten P, Sarathchandra P, Antoniw JW, Tay SS, Lowdell MW, Taylor PM, Yacoub MH. 2006. Human mesenchymal stem cells induce $\mathrm{T}$ cell anergy and downregulate $\mathrm{T}$ cell allo-responses via the TH2 pathway: Relevance to tissue engineering human heart valves. Tissue Eng 12: $2263-$ 2273.

Beggs KJ, Lyubimov A, Borneman JN, Bartholomew A, Moseley A, Dodds R, Archambault MP, Smith AK, McIntosh KR. 2006. Immunologic consequences of multiple, high-dose administration of allogeneic mesenchymal stem cells to baboons. Cell Transplant 15: 711-721.

Caplan AI, Dennis JE. 2006. Mesenchymal stem cells as trophic mediators. J Cell Biochem 98: 1076-1084.

Casiraghi F, Azzollini N, Cassis P, Imberti B, Morigi M, Cugini D, Cavinato RA, Todeschini M, Solini S, Sonzogni A, et al. 2008. Pretransplant infusion of mesenchymal stem cells prolongs the survival of a semiallogeneic heart transplant through the generation of regulatory T cells. J Immunol 181: 3933-3946.

Casiraghi F, Azzollini N, Todeschini M, Cavinato RA, Cassis P, Solini S, Rota C, Morigi M, Introna M, Maranta R, et al. 2012. Localization of mesenchymal stromal cells dictates their immune or proinflammatory effects in kidney transplantation. Am J Transplant 12: 2373-2383.

Chen YT, Sun CK, Lin YC, Chang LT, Chen YL, Tsai TH, Chung SY, Chua S, Kao YH, Yen CH, et al. 2011. Adiposederived mesenchymal stem cell protects kidneys against ischemia-reperfusion injury through suppressing oxidative stress and inflammatory reaction. J Transl Med 9: 51.

Chen S, Chen L, Wu X, Lin J, Fang J, Chen X, Wei S, Xu J, Gao Q, Kang M. 2012. Ischemia postconditioning and mesenchymal stem cells engraftment synergistically attenuate ischemia reperfusion-induced lung injury in rats. J Surg Res 178: 81-91.

Chiesa S, Morbelli S, Morando S, Massollo M, Marini C, Bertoni A, Frassoni F, Bartolome ST, Sambuceti G, Traggiai E, et al. 2011. Mesenchymal stem cells impair in vivo T-cell priming by dendritic cells. Proc Natl Acad Sci 108: 17384-17389.

Choi H, Lee RH, Bazhanov N, Oh JY, Prockop DJ. 2011. Anti-inflammatory protein TSG-6 secreted by activated MSCs attenuates zymosan-induced mouse peritonitis by 
decreasing TLR2/NF- $\mathrm{KB}$ signaling in resident macrophages. Blood 118: 330-338.

Comoli P, Ginevri F, Maccario R, Avanzini MA, Marconi M, Groff A, Cometa A, Cioni M, Porretti L, Barberi W, et al. 2008. Human mesenchymal stem cells inhibit antibody production induced in vitro by allostimulation. Nephrol Dial Transplant 23: 1196-1202.

Corcione A, Benvenuto F, Ferretti E, Giunti D, Cappiello V, Cazzanti F, Risso M, Gualandi F, Mancardi GL, Pistoia V, et al. 2006. Human mesenchymal stem cells modulate Bcell functions. Blood 107: 367-372.

Cutler AJ, Limbani V, Girdlestone J, Navarrete CV. 2010. Umbilical cord-derived mesenchymal stromal cells modulate monocyte function to suppress $\mathrm{T}$ cell proliferation. J Immunol 185: 6617-6623.

Ding YC, Xu DM, Feng G, Bushell A, Muschel RJ, Wood KJ 2009. Mesenchymal stem cells prevent the rejection of fully allogenic islet grafts by the immunosuppressive activity of matrix metalloproteinase-2 and -9. Diabetes 58: 1797-1806.

Di Nicola M, Carlo-Stella C, Magni M, Milanesi M, Longoni PD, Matteucci P, Grisanti S, Gianni AM. 2002 Human bone marrow stromal cells suppress T-lymphocyte proliferation induced by cellular or nonspecific mitogenic stimuli. Blood 99: 3838-3843.

Djouad F, Charbonnier LM, Bouffi C, Louis-Plence P, Bony C, Apparailly F, Cantos C, Jorgensen C, Noel D. 2007. Mesenchymal stem cells inhibit the differentiation of dendritic cells through an interleukin-6-dependent mechanism. Stem Cells 25: 2025-2032.

Dominici M, Le Blanc K, Mueller I, Slaper-Cortenbach I, Marini FC, Krause DS, Deans RJ, Keating A, Prockop DJ, Horwitz EM. 2006. Minimal criteria for defining multipotent mesenchymal stromal cells. The International Society for Cellular Therapy position statement. Cytotherapy 8: 315-317.

Du T, Cheng J, Zhong L, Zhao XF, Zhu J, Zhu YJ, Liu GH. 2012. The alleviation of acute and chronic kidney injury by human Wharton's jelly-derived mesenchymal stromal cells triggered by ischemia-reperfusion injury via an endocrine mechanism. Cytotherapy 14: 1215-1227.

Duffy MM, Pindjakova J, Hanley SA, McCarthy C, Weidhofer GA, Sweeney EM, English K, Shaw G, Murphy JM Barry FP, et al. 2011. Mesenchymal stem cell inhibition of T-helper 17 cell- differentiation is triggered by cell-cell contact and mediated by prostaglandin $\mathrm{E}_{2}$ via the EP4 receptor. Eur J Immunol 41: 2840-2851.

Eggenhofer E, Renner P, Soeder Y, Popp FC, Hoogduijn MJ, Geissler EK, Schlitt HJ, Dahlke MH. 2011a. Features of synergism between mesenchymal stem cells and immunosuppressive drugs in a murine heart transplantation model. Transpl Immunol 25: 141-147.

Eggenhofer E, Steinmann JF, Renner P, Slowik P, Piso P, Geissler EK, Schlitt HJ, Dahlke MH, Popp FC. 2011 . Mesenchymal stem cells together with mycophenolate mofetil inhibit antigen presenting cell and T cell infiltration into allogeneic heart grafts. Transpl Immunol 24: 157-163.

Eliopoulos N, Stagg J, Lejeune L, Pommey S, Galipeau J. 2005. Allogeneic marrow stromal cells are immune rejected by MHC class I- and class II-mismatched recipient mice. Blood 106: 4057-4065.
Eltzschig HK, Eckle T. 2011. Ischemia and reperfusionfrom mechanism to translation. Nat Med 17: 1391-1401.

English K. 2013. Mechanisms of mesenchymal stromal cell immunomodulation. Immunol Cell Biol 91: 19-26.

English K, Mahon BP. 2011. Allogeneic mesenchymal stem cells: Agents of immune modulation. J Cell Biochem 112: 1963-1968.

English K, Barry FP, Field-Corbett CP, Mahon BP. 2007. IFN- $\gamma$ and TNF- $\alpha$ differentially regulate immunomodulation by murine mesenchymal stem cells. Immunol Lett 110: $91-100$.

English K, Barry FP, Mahon BP. 2008. Murine mesenchymal stem cells suppress dendritic cell migration, maturation and antigen presentation. Immunol Lett 115: 50-58.

English K, Ryan JM, Tobin L, Murphy MJ, Barry FP, Mahon BP. 2009. Cell contact, prostaglandin $\mathrm{E}_{2}$ and transforming growth factor $\beta 1$ play non-redundant roles in human mesenchymal stem cell induction of $\mathrm{CD}^{+} \mathrm{CD} 25^{\text {high- }}$ forkhead box $\mathrm{P}^{+}$regulatory $\mathrm{T}$ cells. Clin Exp Immunol 156: $149-160$.

Fiorina P, Jurewicz M, Augello A, Vergani A, Dada S, La Rosa S, Selig M, Godwin J, Law K, Placidi C, et al. 2009. Immunomodulatory function of bone marrow-derived mesenchymal stem cells in experimental autoimmune type 1 diabetes. J Immunol 183: 993-1004.

Francois M, Romieu-Mourez R, Li M, Galipeau J. 2012. Human MSC suppression correlates with cytokine induction of indoleamine 2,3-dioxygenase and bystander M2 macrophage differentiation. Mol Ther 20: 187-195.

Franquesa M, Herrero E, Torras J, Ripoll E, Flaquer M, Goma M, Lloberas N, Anegon I, Cruzado JM, Grinyo JM, et al. 2012a. Mesenchymal stem cell therapy prevents interstitial fibrosis and tubular atrophy in a rat kidney allograft model. Stem Cells Dev 21: 3125-3135.

Franquesa M, Hoogduijn MJ, Bestard O, Grinyo JM. 2012b. Immunomodulatory effect of mesenchymal stem cells on B cells. Front Immunol 3: 212.

Friedenstein AJ, Gorskaja JF, Kulagina NN. 1976. Fibroblast precursors in normal and irradiated mouse hematopoietic organs. Exp Hematol 4: 267-274.

Gatti S, Bruno S, Deregibus MC, Sordi A, Cantaluppi V, Tetta C, Camussi G. 2011. Microvesicles derived from human adult mesenchymal stem cells protect against ischaemia-reperfusion-induced acute and chronic kidney injury. Nephrol Dial Transplant 26: 1474-1483.

Ge W, Jiang J, Baroja ML, Arp J, Zassoko R, Liu W, Bartholomew A, Garcia B, Wang H. 2009. Infusion of mesenchymal stem cells and rapamycin synergize to attenuate alloimmune responses and promote cardiac allograft tolerance. Am J Transplant 9: 1760-1772.

Ge W, Jiang J, Arp J, Liu W, Garcia B, Wang H. 2010. Regulatory T-cell generation and kidney allograft tolerance induced by mesenchymal stem cells associated with indoleamine 2,3-dioxygenase expression. Transplantation 90: $1312-1320$.

Ghannam S, Pene J, Torcy-Moquet G, Jorgensen C, Yssel H. 2010. Mesenchymal stem cells inhibit human Th17 cell differentiation and function and induce a T regulatory cell phenotype. J Immunol 185: 302-312. 
Glennie S, Soeiro I, Dyson PJ, Lam EW, Dazzi F. 2005. Bone marrow mesenchymal stem cells induce division arrest anergy of activated T cells. Blood 105: 2821-2827.

Griffin MD, Ryan AE, Alagesan S, Lohan P, Treacy O, Ritter T. 2013. Anti-donor immune responses elicited by allogeneic mesenchymal stem cells: What have we learned so far? Immunol Cell Biol 91: 40-51.

Halloran PF. 2004. Immunosuppressive drugs for kidney transplantation. N Engl J Med 351: 2715-2729.

Hara Y, Stolk M, Ringe J, Dehne T, Ladhoff J, Kotsch K, Reutzel-Selke A, Reinke P, Volk HD, Seifert M. 2011. In vivo effect of bone marrow-derived mesenchymal stem cells in a rat kidney transplantation model with prolonged cold ischemia. Transpl Int 24: 1112-1123.

Hoogduijn MJ, Popp FC, Grohnert A, Crop MJ, van Rhijn M, Rowshani AT, Eggenhofer E, Renner P, Reinders ME, Rabelink TJ, et al. 2010. Advancement of mesenchymal stem cell therapy in solid organ transplantation (MISOT). Transplantation 90: 124-126.

Huang Y, Chen P, Zhang CB, Ko GJ, Ruiz M, Fiorina P, Hussain MA, Wasowska BA, Rabb H, Womer KL. 2010. Kidney-derived mesenchymal stromal cells modulate dendritic cell function to suppress alloimmune responses and delay allograft rejection. Transplantation 90: 13071311.

Inoue S, Popp FC, Koehl GE, Piso P, Schlitt HJ, Geissler EK, Dahlke MH. 2006. Immunomodulatory effects of mesenchymal stem cells in a rat organ transplant model. Transplantation 81: 1589-1595.

Isakova IA, Dufour J, Lanclos C, Bruhn J, Phinney DG. 2010. Cell-dose-dependent increases in circulating levels of immune effector cells in rhesus macaques following intracranial injection of allogeneic MSCs. Exp Hematol 38: 957-967.

Issa F, Chandrasekharan D, Wood KJ. 2011. Regulatory T cells as modulators of chronic allograft dysfunction. Curr Opin Immunol 23: 648-654.

Jia Z, Jiao C, Zhao S, Li X, Ren X, Zhang L, Han ZC, Zhang X. 2012. Immunomodulatory effects of mesenchymal stem cells in a rat corneal allograft rejection model. Exp Eye Res 102: 44-49.

Kavanagh H, Mahon BP. 2011. Allogeneic mesenchymal stem cells prevent allergic airway inflammation by inducing murine regulatory T cells. Allergy 66: 523-531.

Kemp K, Hares K, Mallam E, Heesom KJ, Scolding N, Wilkins A. 2010. Mesenchymal stem cell-secreted superoxide dismutase promotes cerebellar neuronal survival. J Neurochem 114: 1569-1580.

Kim J, Hematti P. 2009. Mesenchymal stem cell-educated macrophages: A novel type of alternatively activated macrophages. Exp Hematol 37: 1445-1453.

Kim HS, Shin TH, Yang SR, Seo MS, Kim DJ, Kang SK, Park JH, Kang KS. 2010. Implication of NOD1 and NOD2 for the differentiation of multipotent mesenchymal stem cells derived from human umbilical cord blood. PLOS ONE 5: e15369.

Kong QF, Sun B, Bai SS, Zhai DX, Wang GY, Liu YM, Zhang SJ, Li R, Zhao W, Sun YY, et al. 2009. Administration of bone marrow stromal cells ameliorates experimental autoimmune myasthenia gravis by altering the balance of Th1/Th2/Th17/Treg cell subsets through the secretion of TGF- $\beta$. J Neuroimmunol 207: 83-91.
Kume S, Kato S, Yamagishi S, Inagaki Y, Ueda S, Arima N, Okawa T, Kojiro M, Nagata K. 2005. Advanced glycation end-products attenuate human mesenchymal stem cells and prevent cognate differentiation into adipose tissue, cartilage, and bone. J Bone Miner Res 20: 1647-1658.

LeBlanc K, Frassoni F, Ball L, Locatelli F, Roelofs H, Lewis I, Lanino E, Sundberg B, Bernardo ME, Remberger M, et al. 2008. Mesenchymal stem cells for treatment of steroidresistant, severe, acute graft-versus-host disease: A phase II study. Lancet 371: 1579-1586.

Li H, Guo ZK, Jiang XX, Zhu H, Li XS, Mao N. 2008a. Mesenchymal stem cells alter migratory property of $\mathrm{T}$ and dendritic cells to delay the development of murine lethal acute graft-versus-host disease. Stem Cells 26: 25312541.

Li YP, Paczesny S, Lauret E, Poirault S, Bordigoni P, Mekhloufi F, Hequet O, Bertrand Y, Ou-Yang JP, Stoltz JF, et al. 2008b. Human mesenchymal stem cells license adult $\mathrm{CD} 34^{+}$hemopoietic progenitor cells to differentiate into regulatory dendritic cells through activation of the notch pathway. J Immunol 180: 1598-1608.

Liotta F, Angeli R, Cosmi L, Fili L, Manuelli C, Frosali F, Mazzinghi B, Maggi L, Pasini A, Lisi V, et al. 2008. Tolllike receptors 3 and 4 are expressed by human bone marrow-derived mesenchymal stem cells and can inhibit their T-cell modulatory activity by impairing Notch signaling. Stem Cells 26: 279-289.

Liu H, Liu S, Li Y, Wang X, Xue W, Ge G, Luo X. 2012a. The role of SDF-1-CXCR4/CXCR7 axis in the therapeutic effects of hypoxia-preconditioned mesenchymal stem cells for renal ischemia/reperfusion injury. PLOS ONE 7: e34608.

Liu X, Qu X, Chen Y, Liao L, Cheng K, Shao C, Zenke M, Keating A, Zhao RC. 2012b. Mesenchymal stem/stromal cells induce the generation of novel IL-10-dependent regulatory dendritic cells by SOCS3 activation. J Immunol 189: $1182-1192$

Lotfi R, Eisenbacher J, Solgi G, Fuchs K, Yildiz T, Nienhaus C, Rojewski MT, Schrezenmeier H. 2011. Human mesenchymal stem cells respond to native but not oxidized damage associated molecular pattern molecules from necrotic (tumor) material. Eur J Immunol 41: 2021-2028.

Maggini J, Mirkin G, Bognanni I, Holmberg J, Piazzon IM, Nepomnaschy I, Costa H, Canones C, Raiden S, Vermeulen M, et al. 2010. Mouse bone marrow-derived mesenchymal stromal cells turn activated macrophages into a regulatory-like profile. PLoS ONE 5: e9252.

Mahmood A, Lu D, Lu M, Chopp M. 2003. Treatment of traumatic brain injury in adult rats with intravenous ad ministration of human bone marrow stromal cells. $\mathrm{Neu}$ rosurgery 53: 697-702; discussion 702-703.

Moll G, Jitschin R, von Bahr L, Rasmusson-Duprez I, Sundberg B, Lonnies L, Elgue G, Nilsson-Ekdahl K, Mougiakakos D, Lambris JD, et al. 2011. Mesenchymal stromal cells engage complement and complement receptor bearing innate effector cells to modulate immune responses. PLoS ONE 6: e21703.

Mougiakakos D, Jitschin R, Johansson CC, Okita R, Kiessling R, Le Blanc K. 2011. The impact of inflammatory licensing on heme oxygenase-1-mediated induction of regulatory $\mathrm{T}$ cells by human mesenchymal stem cells. Blood 117: 4826-4835. 
MSCs in Transplantation

Murphy JM, Fink DJ, Hunziker EB, Barry FP. 2003. Stem cell therapy in a caprine model of osteoarthritis. Arthritis Rheum 48: 3464-3474.

Nauta AJ, Kruisselbrink AB, Lurvink E, Willemze R, Fibbe WE. 2006a. Mesenchymal stem cells inhibit generation and function of both $\mathrm{CD} 34^{+}$-derived and monocyte-derived dendritic cells. J Immunol 177: 2080-2087.

Nauta AJ, Westerhuis G, Kruisselbrink AB, Lurvink EG, Willemze R, Fibbe WE. 2006b. Donor-derived mesenchymal stem cells are immunogenic in an allogeneic host and stimulate donor graft rejection in a nonmyeloablative setting. Blood 108: 2114-2120.

Nemeth K, Leelahavanichkul A, Yuen PST, Mayer B, Parmelee A, Doi K, Robey PG, Leelahavanichkul K, Koller BH, Brown JM, et al. 2009. Bone marrow stromal cells attenuate sepsis via prostaglandin $\mathrm{E}_{2}$-dependent reprogramming of host macrophages to increase their interleukin-10 production. Nat Med 15: 42-49.

Nemeth K, Keane-Myers A, Brown JM, Metcalfe DD, Gorham JD, Bundoc VG, Hodges MG, Jelinek I, Madala S, Karpati S, et al. 2010. Bone marrow stromal cells use TGF$\beta$ to suppress allergic responses in a mouse model of ragweed-induced asthma. Proc Natl Acad Sci 107: 56525657.

Ogura Y, Sutterwala FS, Flavell RA. 2006. The inflammasome: First line of the immune response to cell stress. Cell 126: 659-662.

Oh JY, Lee RH, Yu JM, Ko JH, Lee HJ, Ko AY, Roddy GW, Prockop DJ. 2012. Intravenous mesenchymal stem cells prevented rejection of allogeneic corneal transplants by aborting the early inflammatory response. Mol Ther 20: 2143-2152.

Opitz CA, Litzenburger UM, Lutz C, Lanz TV, Tritschler I, Koppel A, Tolosa E, Hoberg M, Anderl J, Aicher WK, et al. 2009. Toll-like receptor engagement enhances the immunosuppressive properties of human bone marrow-derived mesenchymal stem cells by inducing indoleamine2,3-dioxygenase-1 via interferon- $\beta$ and protein kinase $\mathrm{R}$. Stem Cells 27: 909-919.

Perico N, Casiraghi F, Introna M, Gotti E, Todeschini M, Cavinato RA, Capelli C, Rambaldi A, Cassis P, Rizzo P, et al. 2011. Autologous mesenchymal stromal cells and kidney transplantation: A pilot study of safety and clinical feasibility. Clin J Am Soc Nephrol 6: 412-422.

Pevsner-Fischer M, Morad V, Cohen-Sfady M, RoussoNoori L, Zanin-Zhorov A, Cohen S, Cohen IR, Zipori D. 2007. Toll-like receptors and their ligands control mesenchymal stem cell functions. Blood 109: 1422-1432.

Pittenger MF, Mackay AM, Beck SC, Jaiswal RK, Douglas R, Mosca JD, Moorman MA, Simonetti DW, Craig S, Marshak DR. 1999. Multilineage potential of adult human mesenchymal stem cells. Science 284: 143-147.

Polchert D, Sobinsky J, Douglas G, Kidd M, Moadsiri A, Reina E, Genrich K, Mehrotra S, Setty S, Smith B, et al. 2008. IFN- $\gamma$ activation of mesenchymal stem cells for treatment and prevention of graft versus host disease. Eur J Immunol 38: 1745-1755.

Poncelet AJ, Nizet Y, Vercruysse J, Hiel AL, Saliez A, Gianello P. 2008. Inhibition of humoral response to allogeneic porcine mesenchymal stem cell with 12 days of tacrolimus. Transplantation 86: 1586-1595.
Popp FC, Eggenhofer E, Renner P, Slowik P, Lang SA, Kaspar H, Geissler EK, Piso P, Schlitt HJ, Dahlke MH. 2008. Mesenchymal stem cells can induce long-term acceptance of solid organ allografts in synergy with lowdose mycophenolate. Transpl Immunol 20: 55-60.

Prockop DJ. 2009. Repair of tissues by adult stem/progenitor cells (MSCs): Controversies, myths, and changing paradigms. Mol Ther 17: 939-946.

Qiu Y, Marquez-Curtis LA, Janowska-Wieczorek A. 2012. Mesenchymal stromal cells derived from umbilical cord blood migrate in response to complement C1q. Cytotherapy 14: 285-295.

Rafei M, Hsieh J, Fortier S, Li MY, Yuan S, Birman E, Forner K, Boivin MN, Doody K, Tremblay M, et al. 2008. Mesenchymal stromal cell-derived CCL2 suppresses plasma cell immunoglobulin production via STAT3 inactivation and PAX5 induction. Blood 112: 4991-4998.

Rafei M, Campeau PA, Aguilar-Mahecha A, Buchanan M, Williams P, Birman E, Yuan S, Young YK, Boivin MN, Forner K, et al. 2009. Mesenchymal stromal cells ameliorate experimental autoimmune encephalomyelitis by inhibiting CD4 Th17 T cells in a CC chemokine ligand 2dependent manner. J Immunol 182: 5994-6002.

Rasmusson I, Le Blanc K, Sundberg B, Ringden O. 2007. Mesenchymal stem cells stimulate antibody secretion in human B cells. Scand J Immunol 65: 336-343.

Ren GW, Zhang LY, Zhao X, Xu GW, Zhang YY, Roberts AI, Zhao RC, Shi YF. 2008. Mesenchymal stem cell-mediated immunosuppression occurs via concerted action of chemokines and nitric oxide. Cell Stem Cell 2: 141150.

Renner P, Eggenhofer E, Rosenauer A, Popp FC, Steinmann JF, Slowik P, Geissler EK, Piso P, Schlitt HJ, Dahlke MH. 2009. Mesenchymal stem cells require a sufficient, ongoing immune response to exert their immunosuppressive function. Transplant Proc 41: 2607-2611.

Romieu-Mourez R, Francois M, Boivin MN, Bouchentouf M, Spaner DE, Galipeau J. 2009. Cytokine modulation of TLR expression and activation in mesenchymal stromal cells leads to a proinflammatory phenotype. $J$ Immunol 182: 7963-7973.

Schena F, Gambini C, Gregorio A, Mosconi M, Reverberi D, Gattorno M, Casazza S, Uccelli A, Moretta L, Martini A, et al. 2010. Interferon- $\gamma$-dependent inhibition of B cell activation by bone marrow-derived mesenchymal stem cells in a murine model of systemic lupus erythematosus. Arthritis Rheum 62: 2776-2786.

Schraufstatter IU, Discipio RG, Zhao M, Khaldoyanidi SK. 2009. C3a and C5a are chemotactic factors for human mesenchymal stem cells, which cause prolonged ERK1/2 phosphorylation. J Immunol 182: 3827-3836.

Schu S, Nosov M, O’Flynn L, Shaw G, Treacy O, Barry F, Murphy M, O’Brien T, Ritter T. 2012. Immunogenicity of allogeneic mesenchymal stem cells. J Cell Mol Med 16: 2094-2103.

Seifert M, Stolk M, Polenz D, Volk HD. 2012. Detrimental effects of rat mesenchymal stromal cell pre-treatment in a model of acute kidney rejection. Front Immunol 3: 202.

Selmani Z, Naji A, Zidi I, Favier B, Gaiffe E, Obert L, Borg C, Saas P, Tiberghien P, Rouas-Freiss N, et al. 2008. Human leukocyte antigen-G5 secretion by human mesenchymal stem cells is required to suppress $\mathrm{T}$ lymphocyte 
and natural killer function and to induce $\mathrm{CD} 4{ }^{+} \mathrm{CD} 25^{\text {high }}$ $\mathrm{FOXP}^{+}{ }^{+}$regulatory T cells. Stem Cells 26: 212-222.

Sica A, Mantovani A. 2012. Macrophage plasticity and polarization: In vivo veritas. J Clin Invest 122: 787-795.

Sioud M, Mobergslien A, Boudabous A, Floisand Y. 2010 Evidence for the involvement of galectin-3 in mesenchymal stem cell suppression of allogeneic T-cell proliferation. Scand J Immunol 71: 267-274.

Spaggiari GM, Capobianco A, Becchetti S, Mingari MC, Moretta L. 2006. Mesenchymal stem cell-natural killer cell interactions: Evidence that activated NK cells are capable of killing MSCs, whereas MSCs can inhibit IL-2induced NK-cell proliferation. Blood 107: 1484-1490.

Spaggiari GM, Abdelrazik H, Becchetti F, Moretta L. 2009. MSCs inhibit monocyte-derived DC maturation and function by selectively interfering with the generation of immature DCs: Central role of MSC-derived prostaglandin $\mathrm{E}_{2}$. Blood 113: 6576-6583.

Sun CK, Yen CH, Lin YC, Tsai TH, Chang LT, Kao YH, Chua S, Fu M, Ko SF, Leu S, et al. 2011. Autologous transplantation of adipose-derived mesenchymal stem cells markedly reduced acute ischemia-reperfusion lung injury in a rodent model. J Transl Med 9: 118.

Tabera S, Perez-Simon JA, Diez-Campelo M, SanchezAbarca LI, Blanco B, Lopez A, Benito A, Ocio E, SanchezGuijo FM, Canizo C, et al. 2008. The effect of mesenchymal stem cells on the viability, proliferation and differentiation of B-lymphocytes. Haematologica 93: 13011309.

Tan J, Wu W, Xu X, Liao L, Zheng F, Messinger S, Sun X, Chen J, Yang S, Cai J, et al. 2012. Induction therapy with autologous mesenchymal stem cells in living-related kidney transplants: A randomized controlled trial. JAMA 307: 1169-1177.

Tatara R, Ozaki K, Kikuchi Y, Hatanaka K, Oh I, Meguro A Matsu H, Sato K, Ozawa K. 2011. Mesenchymal stromal cells inhibit Th17 but not regulatory T-cell differentiation. Cytotherapy 13: 686-694.

Tomchuck SL, Zwezdaryk KJ, Coffelt SB, Waterman RS, Danka ES, Scandurro AB. 2008. Toll-like receptors on human mesenchymal stem cells drive their migration and immunomodulating responses. Stem Cells 26: 99107.

Traggiai E, Volpi S, Schena F, Gattorno M, Ferlito F Moretta L, Martini A. 2008. Bone marrow-derived mesenchymal stem cells induce both polyclonal expansion and differentiation of $\mathrm{B}$ cells isolated from healthy donors and systemic lupus erythematosus patients. Stem Cells 26: $562-569$.

Tu Z, Li Q, Bu H, Lin F. 2010. Mesenchymal stem cells inhibit complement activation by secreting factor $\mathrm{H}$. Stem Cells Dev 19: 1803-1809.

Wang Y, Zhang A, Ye Z, Xie H, Zheng S. 2009. Bone marrowderived mesenchymal stem cells inhibit acute rejection of rat liver allografts in association with regulatory T-cell expansion. Transplant Proc 41: 4352-4356.

Waterman RS, Tomchuck SL, Henkle SL, Betancourt AM. 2010. A new mesenchymal stem cell (MSC) paradigm: Polarization into a pro-inflammatory MSC1 or an immunosuppressive MSC2 phenotype. PLoS ONE 5: e10088.

Wood KJ, Goto R. 2012. Mechanisms of rejection: Current perspectives. Transplantation 93: 1-10.

Wood KJ, Bushell A, Hester J. 2012. Regulatory immune cells in transplantation. Nat Rev Immunol 12: 417-430.

Wyburn KR, Jose MD, Wu H, Atkins RC, Chadban SJ. 2005. The role of macrophages in allograft rejection. Transplantation 80: 1641-1647.

Youd M, Blickarz C, Woodworth L, Touzjian T, Edling A, Tedstone J, Ruzek M, Tubo R, Kaplan J, Lodie T. 2010 Allogeneic mesenchymal stem cells do not protect NZBxNZW F1 mice from developing lupus disease. Clin Exp Immunol 161: 176-186.

Zangi L, Margalit R, Reich-Zeliger S, Bachar-Lustig E, Beilhack A, Negrin R, Reisner Y. 2009. Direct imaging of immune rejection and memory induction by allogeneic mesenchymal stromal cells. Stem Cells 27: 2865 2874.

Zhang B, Liu R, Shi D, Liu XX, Chen Y, Dou XW, Zhu XS, Lu CH, Liang W, Liao LM, et al. 2009. Mesenchymal stem cells induce mature dendritic cells into a novel Jagged-2dependent regulatory dendritic cell population. Blood 113: 46-57.

Zhao W, Wang Y, Wang D, Sun B, Wang G, Wang J, Kong Q, Wang Q, Peng H, Jin L, et al. 2008. TGF- $\beta$ expression by allogeneic bone marrow stromal cells ameliorates diabetes in NOD mice through modulating the distribution of $\mathrm{CD}^{+} \mathrm{T}$ cell subsets. Cell Immunol 253: 23-30.

Zhou K, Zhang H, Jin O, Feng X, Yao G, Hou Y, Sun L. 2008. Transplantation of human bone marrow mesenchymal stem cell ameliorates the autoimmune pathogenesis in MRL/lpr mice. Cell Mol Immunol 5: 417-424. 


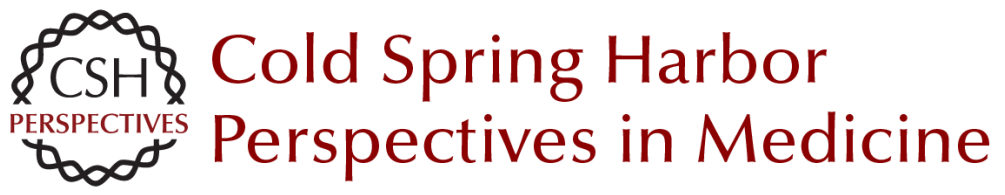

\section{Mesenchymal Stromal Cells in Transplantation Rejection and Tolerance}

Karen English and Kathryn J. Wood

Cold Spring Harb Perspect Med 2013; doi: 10.1101/cshperspect.a015560

Subject Collection Transplantation

Heart Transplantation: Challenges Facing the Field

Makoto Tonsho, Sebastian Michel, Zain Ahmed, et al.

Bioethics of Organ Transplantation Arthur Caplan

Overview of Clinical Lung Transplantation Jonathan C. Yeung and Shaf Keshavjee

Immunological Challenges and Therapies in

Xenotransplantation Marta Vadori and Emanuele Cozzi

Clinical Aspects: Focusing on Key Unique Organ-Specific Issues of Renal Transplantation Sindhu Chandran and Flavio Vincenti

T-Cell Costimulatory Blockade in Organ

Transplantation Jonathan S. Maltzman and Laurence A. Turka

Regulatory T-Cell Therapy in Transplantation: Moving to the Clinic Qizhi Tang and Jeffrey A. Bluestone

Opportunistic Infections--Coming to the Limits of Immunosuppression? Jay A. Fishman
Overview of the Indications and Contraindications for Liver Transplantation

Stefan Farkas, Christina Hackl and Hans Jürgen Schlitt

Facial and Hand Allotransplantation Bohdan Pomahac, Ryan M. Gobble and Stefan Schneeberger

Induction of Tolerance through Mixed Chimerism David H. Sachs, Tatsuo Kawai and Megan Sykes

Pancreas Transplantation: Solid Organ and Islet Shruti Mittal, Paul Johnson and Peter Friend

Tolerance--Is It Worth It? Erik B. Finger, Terry B. Strom and Arthur J. Matas

Lessons and Limits of Mouse Models Anita S. Chong, Maria-Luisa Alegre, Michelle L. Miller, et al.

Effector Mechanisms of Rejection Aurélie Moreau, Emilie Varey, Ignacio Anegon, et al.

The Innate Immune System and Transplantation Conrad A. Farrar, Jerzy W. Kupiec-Weglinski and Steven H. Sacks

For additional articles in this collection, see http://perspectivesinmedicine.cshlp.org/cgi/collection/ 